\title{
Potentials and limits of urban rainwater harvesting in the Middle East
}

\author{
J. Lange ${ }^{1}$, S. Husary ${ }^{2, *}$, A. Gunkel ${ }^{1}$, D. Bastian ${ }^{1}$, and T. Grodek ${ }^{3}$ \\ ${ }^{1}$ Institute of Hydrology, University of Freiburg, Fahnenbergplatz, 79098 Freiburg, Germany \\ ${ }^{2}$ Palestinian Hydrology Group, P.O. Box 565, Ramallah, Palestinian National Authority \\ ${ }^{3}$ Geography Department, The Hebrew University of Jerusalem, Mt. Scopus, Jerusalem, 91905, Israel \\ *now at: Welfare Association, Al Nahda Square, Canada St., Ramallah, Palestinian National Authority
}

Correspondence to: J. Lange (jens.lange@hydrology.uni-freiburg.de)

Received: 14 October 2011 - Published in Hydrol. Earth Syst. Sci. Discuss.: 25 November 2011

Revised: 26 February 2012 - Accepted: 27 February 2012 - Published: 6 March 2012

\begin{abstract}
In the Middle East, water is scarce and population growth causes a rapid rise of urban centers. Since many towns of the Palestinian Authority (PA) suffer from water shortage, the use of rainwater harvesting (RWH) as an alternative to conventional water supply has gained increasing interest among water resources planners. This study quantifies actual volumes of urban RWH to be expected from highly variable Mediterranean rainfall. A one-parameter model uses measured potential evaporation and high resolution rainfall data as input to calculate RWH volumes from rooftops inside Ramallah, a traditional Arab town. While during average seasons a $87 \%$ runoff harvest (480 from $550 \mathrm{~mm}$ of rainfall) can be expected, this value decreases to about $75 \%$ (190 from $250 \mathrm{~mm}$ of rainfall) during drought seasons. A survey comprising more than 500 questionnaires suggests that approximately $40 \%$ of the houses are equipped with RWH systems from which one third are out of use. Although water quality is perceived to be favourable, only $3 \%$ of the active RWH systems are actually used for drinking and only $18 \%$ for domestic purposes. All active RWH systems investigated may harvest approximately $16 \times 10^{3} \mathrm{~m}^{3}$ of rooftop runoff during an average season and $6 \times 10^{3} \mathrm{~m}^{3}$ during droughts. When these numbers are extrapolated to all houses in Ramallah, theoretical maximum potentials increase to approximately $298 \times 10^{3} \mathrm{~m}^{3}$ during average seasons and $118 \times 10^{3} \mathrm{~m}^{3}$ during droughts. A part of this potential can easily be exhausted by rehabilitation of installed RWH systems. The use of RWH for emergency water supply should be advocated, although care is needed because of hygienic risks. Regional estimates for the entire Lower Jordan River Basin yielded RWH potentials of $20 \times 10^{6} \mathrm{~m}^{3}$ during the average season $2002 / 2003$ but only $3 \times 10^{6} \mathrm{~m}^{3}$ during the drought season 1998/1999. Thus, urban RWH is a relatively small
\end{abstract}

contribution to overcome water scarcity in the region and decreases significantly during droughts. Yet it is a sustainable water resource, which is available on spot for everybody. Due to population growth and ongoing urbanization it will be more important in future.

\section{Introduction}

Water is a scarce resource in the Middle East and disputed between national entities, e.g. between Israel and a future State of Palestine (Brooks and Trottier, 2010). At the same time, like in many regions of the world, a tremendous population growth causes a rapid rise of urban centers. Many towns of the Palestinian Authority (PA) suffer from water shortage, which is revealed by regular failures of the water supply systems during summer months. Under these circumstances, the use of rainwater harvesting (RWH) in addition to water from supply networks has gained renewed and increasing interest among water resources planners. Already two-thousand years ago the Nabateans used RWH both for drinking water and for agriculture, making their prehistoric desert civilization flourish (Evenari et al., 1982).

Especially for developing regions, RWH is seen as a valuable water resource, both for agricultural and domestic use (Helmreich and Horn, 2009). In a world-wide overview, Rygaard et al. (2011) identified RWH as an important component to increase self-sufficiency of urban centres, among recycled wastewater and desalinated water. However, a recent case study in Mediterranean Spain showed that RWH may not always be cost-efficient, especially at a low pipe-water price (Farreny et al., 2011a). At conditions of water scarcity, the value of RWH is without controversy, as shown for the 
Indian megacity Chennai (Srinivasan et al., 2010), or for the Kingdom of Jordan (Abdulla and Al-Shareef, 2009).

The current regulatory framework is different in the national entities of the Middle East. According to health regulations, the Israeli Ministry of Health does not permit the use of RWH for drinking and any storage or purification system must be under its strict supervision. This comprehensive regulation prevents any legal use of harvested water for drinking. In the PA comparable limitations do not exist. Instead, the Palestinian Water Authority has given priority to RWH as a part of its water emergency plan (Kittani, 2006). Also the Jordanian Ministry of Water and Irrigation encourages RWH and new houses must be equipped with water storage facilities (Abdulla and Al-Shareef, 2009).

Technically, rainwater is collected at the edge of a roof. The amount of rainwater collected depends on the prevailing climate (rainfall and evaporation), on the rooftop area and on the type of roofing material. Several studies addressed the effect of roof type on the amount of harvested water. Hollis and Ovenden (1988) measured runoff responses from different roof types in the UK and documented the effect of rainfall magnitude. For an entire year they found runoff coefficients of $57 \%$, while during large events $(>5 \mathrm{~mm})$ coefficients increased to more than $90 \%$. Values for roof depression storage ranged between 0.2 and $1.0 \mathrm{~mm}$. Typical textbook values for roof depression storage are $2.54 \mathrm{~mm}(0.1 \mathrm{inch})$ for flat roofs and $1.27 \mathrm{~mm}(0.05 \mathrm{inch})$ for sloping roofs, respectively (Akan and Houghtalen, 2003). Monitoring four different roofs over a period of two years in Spain, Farreny et al. (2011b) quantified depression storages $(0.8-3.8 \mathrm{~mm})$ and runoff coefficients (68-92\%) for different roof types in Mediterranean climate. After rainfall is collected, it is diverted to cisterns to be stored for later use. Thereby the size of the cisterns is important for the efficiency of the RWH system. Jones and Hunt (2010) showed that a typical 2081 rain barrel was too small for the efficient RWH use in North Carolina, US. Water-saving efficiency, overflow ratio and detention time of RWH systems can be optimized by applying a daily mass balance equation to historical rainfall data (Palla et al., 2011). A similar model was fed by precipitation scenarios and used to study the reliability of RWH-systems in New York City (Basinger et al., 2010).

Very often the use of RWH is considered to be restricted by limits in quality. On rooftops the quality of harvested rainwater may be affected by bird droppings or depositions of small mammals, by decay of accumulated organic debris, or by atmospheric deposition of airborne microorganisms and chemical pollutants. Storage cisterns may be a source for bacterial contamination and may be conducive to algal growth and the breeding of mosquitoes. Evans et al. (2006) suggested a significant contribution of airborne micro-organisms to the bacterial load of roof water. Bacteria in collected rainwater posed the largest problems in rural areas of northwest China as well, however, water quality improved significantly by self-purification during storage in cisterns (Zhu et al., 2004). Water quality deficits in the collected roof water caused by bacteria in southwest Greece decreased significantly when roofs were cleaned (Sazakli et al., 2007). Collected rainwater may further by improved by solar disinfection, which proved efficient especially in developing countries (Amin and Han, 2009). In a recent comparison of different roof materials, metal roofs provided waters with best bacterial quality, while modern green roofs showed high dissolved organic carbon concentrations and increased concentrations of some trace metals which originated from growing media (Mendez et al., 2011). Hence, a general conclusion can be drawn that contaminated rooftop runoff appears to be limited to systems that do not have proper design or proper materials (Lye, 2009). However, when the harvested water must be stored for long time periods, which is especially true for the dry Mediterranean summer, adequate treatment/disinfection procedures are required. This was corroborated by a recent study in the southern PA where only bacterial contamination restricted the RWH use (AlSaleymeh et al., 2011).

So far, urban RWH studies in the Middle East have concentrated on water quality (Al-Saleymeh et al., 2011; Hassan et al., 2010) or used country statistics to estimate mean potentials for entire governorates (Abdulla and Al-Shareef, 2009). Based on real data, our study intends to (i) quantify real volumes of urban RWH to be expected from highly variable Mediterranean rainfall in different spatial scales and (ii) show the realized potential for a sample city in the region.

- First, we calculate the amount of harvested rainwater by a one-parameter model with measured potential evaporation and high resolution rainfall data as input. For this we chose the city of Ramallah, a typical Middle-Eastern Arab town.

- Second, we use the results of a survey of more than 500 questionnaires about urban water use. Inhabitants of Ramallah answered questions about actual daily use of rooftop harvested water and its limitations. Questions also included the perceived water quality of the installed systems. By GIS analysis, we identify rooftop areas, extrapolate the results to a $1.3 \mathrm{~km}^{2}$ city district and finally to the entire city.

- Third, we extrapolate our findings to the entire Lower Jordan River Basin (LJRB). To account for climatic variability, we use rainfall radar data sets from a drought and an average season and apply variable runoff coefficients.

\section{Study area}

The $16400 \mathrm{~km}^{2}$ Lower Jordan River Basin (LJRB) is a multinational water basin shared between Israel, Jordan, Syria and the Palestinian Authority (PA) (Fig. 1). Naturally, the Lower 


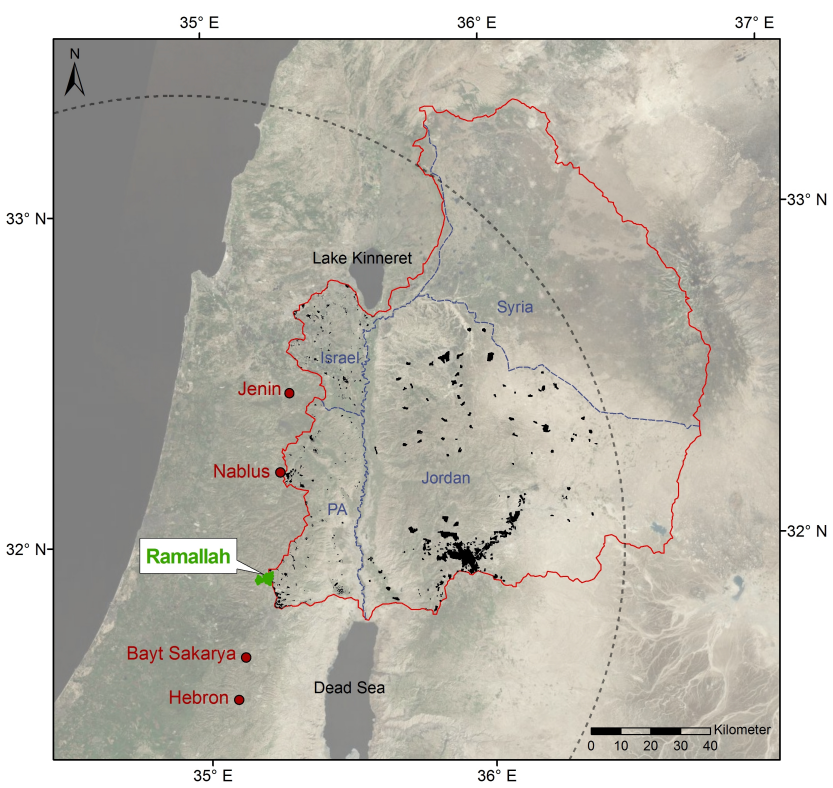

Fig. 1. Location Map: the multi-national Lower Jordan River Basin with its urban areas (black) and the city of Ramallah (green); in red: meteorological stations with available data for measured evaporation; circle indicates the $150 \mathrm{~km}$ range around the rainfall radar.

Jordan River exits Lake Tiberias (210 m b.s.l.) flowing south to the Dead Sea $(410 \mathrm{mb}$ b.s.l.) through the Lower Jordan Rift Valley. To date, only 20 million $\mathrm{m}^{3} \mathrm{yr}^{-1}(2.6 \%)$ are released willingly from Lake Tiberias for agricultural use and for Christian pilgrimage at the Yardenit baptism site (Klein, 1998). As a consequence, the Lower Jordan River is deprived of virtually all natural flow and mainly drains diverted saline spring water, sewage and excess water from irrigation (FOME, 2010). On both sides, the Lower Jordan Rift Valley is bordered by steep escarpments and mountain ranges reaching almost $1000 \mathrm{~m}$ a.s.l. in the PA and $1200 \mathrm{~m}$ a.s.l. in Jordan. This accentuated morphology creates sharp climatic gradients from a Mediterranean-type climate to fully arid. Precipitation is lowest in the Jordan Valley and in the eastern fringes of the LJRB (less than 100-200 mm per year) and highest in mountainous areas (up to $600 \mathrm{~mm}$ per year). There, also most urban centres are found with the Jordanian capital of Amman forming the biggest urban agglomeration. Ramallah is situated opposite to Amman on the crest of the western anticline at $750-850 \mathrm{~m}$ a.s.l. It receives $550 \mathrm{~mm}$ of mean annual precipitation with a range of 240-1200 mm (Morin et al., 1994). Most of the precipitation ( $80 \%$ ) occurs at low intensities (under $6 \mathrm{~mm} \mathrm{~h}^{-1}$ ) and only $1 \%$ falls with intensities exceeding $50 \mathrm{~mm} \mathrm{~h}^{-1}$ (Sharon and Kutiel, 1986). A single rainstorm may last from a few hours up to several days, characterized by several separate rain spells (minutes to hours) interrupted by dry intervals, which can last for several hours.

As a traditional Arab town, Ramallah was built around an old quarter, which is the centre for daily life and small

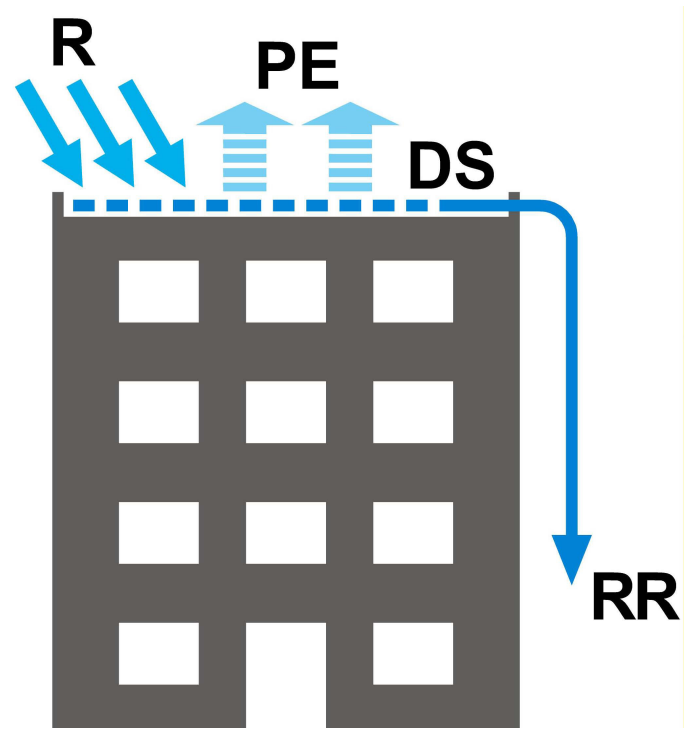

Fig. 2. Conceptual sketch of the rooftop harvesting model; $R$ : rainfall, PE: potential evaporation, DS: depression storage, RR: roof runoff.

commercial businesses. Both modern and traditional houses are found around the city core. The periphery of the inner city also contains rural parts consisting of natural landscape and cultivated terraces. Typically for the Middle East, houses are covered by flat, concrete roofs. In historic times a small spring served as the main water supply. Today, most of the urban area is connected to the drinking water supply by a private water company (Jerusalem Water Undertaking, JWU). JWU owns the Ein Samia well field located $20 \mathrm{~km}$ NE of the city, where five wells tap groundwater at an altitude of $400 \mathrm{~m}$ a.s.l. However, this water is by far not enough to supply the growing demands of the city. Especially during summer, a major fraction must be purchased from external, i.e. Israeli, sources.

\section{Methodology}

\subsection{Amount of harvested rainwater}

A simple, one-parameter model calculated the amount of harvested rooftop rainwater (Fig. 2). In a one minute time step, the roof depression storage DS [mm] was filled with rainfall $R\left[\mathrm{~mm} \mathrm{~min}^{-1}\right]$ and emptied by potential evaporation $\mathrm{PE}\left[\mathrm{mm} \mathrm{min}^{-1}\right]$. Only when DS was reached, the exceeding water was treated as roof runoff RR $\left[\mathrm{mm} \mathrm{min}^{-1}\right]$. Daily CLASS-A-PAN measurements of four meteorological stations (Fig. 1) were averaged and divided by day length [min] for instantaneous potential evaporation. Evaporation was hypothesized to start at sunrise and terminate at sunset. Daily sun data was obtained from the Astronomical Applications Department of the US Naval Observatory (USNO). Finally, 

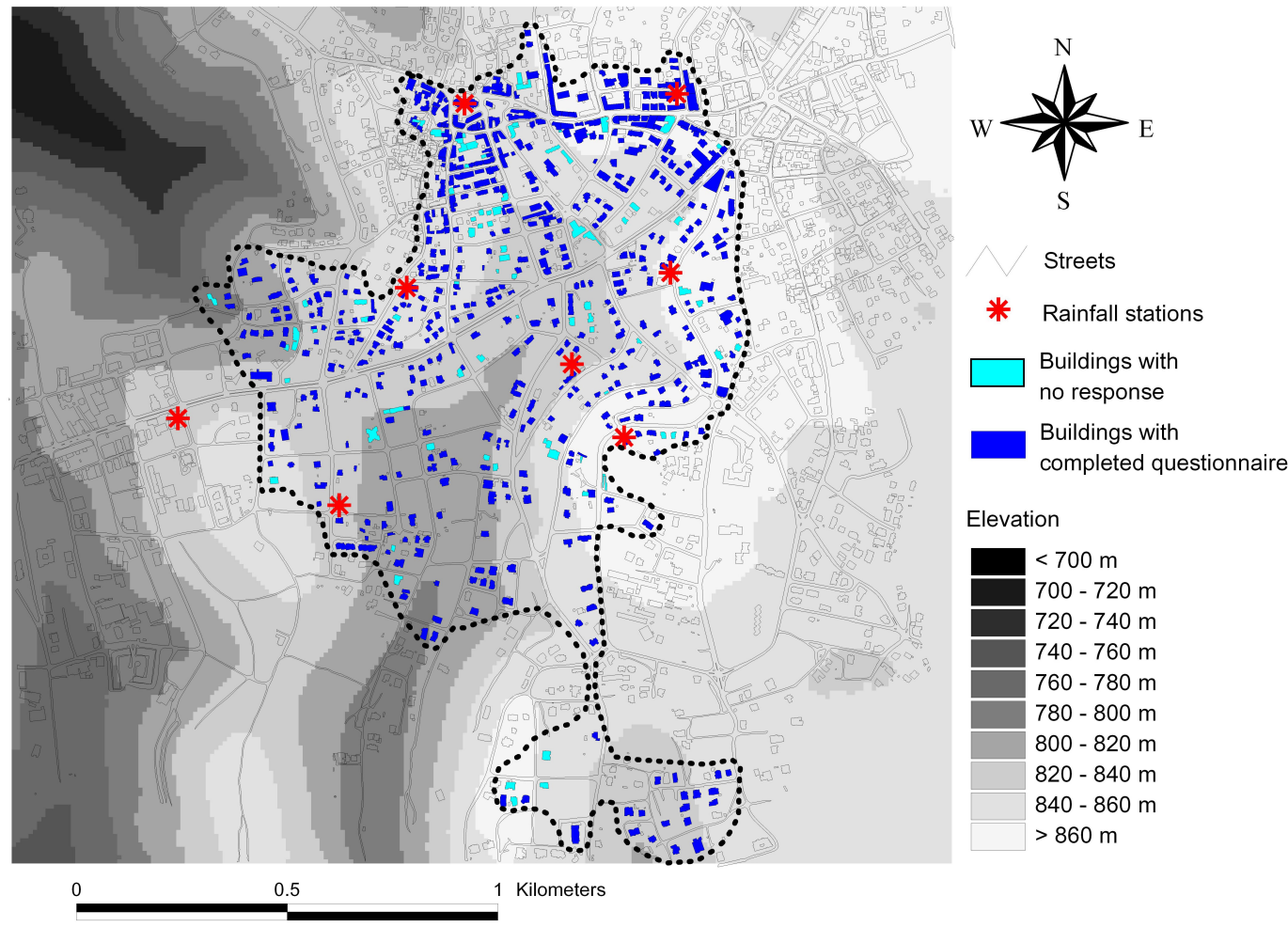

Elevation

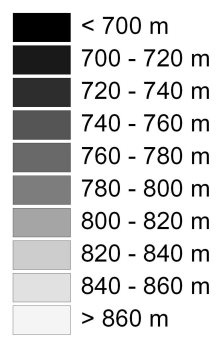

Fig. 3. Investigated city district inside Ramallah, buildings with residents surveyed and installed rainfall stations.

RR values were accumulated to seasonal amounts and divided by seasonal rainfall to arrive at seasonal roof runoff coefficients (RC, \%).

During three winter seasons (1999/2000, 2000/2001 and 2001/2002) rainfall was measured at nine different locations inside Ramallah by rooftop tipping bucket raingauges (Fig. 3). The raw $0.1 \mathrm{~mm}$ tips of ULTIMETER TB Rain Gauges equipped with Hobo event data loggers were accumulated to $1 \mathrm{~min}$ time intervals. Due to instrument failures and limited accessibility following riots inside the town, not a single station measured continuously. Incomplete records were not excluded from the analysis but rather treated in a similar way as independent data from low rainfall seasons. All obtained seasonal RC values were plotted against total rainfall. To assess model uncertainty, the single model parameter DS was varied according to reported values of roof detention storage. This sensitivity analysis also yielded statements about the impact of different roof types on the amount of harvested water.

\subsection{Survey of local residents and cistern efficiency}

Inside the city, all roofs were digitized from a 1:2000 orthophoto of the year 1997. By GIS analysis the total roof area was calculated and individual roofs were assigned to the respondents of the urban questionnaires. 541 of these questionnaires were distributed in a $1.3 \mathrm{~km}^{2}$ district close to the city centre in the summer months of the year 2000 (Fig. 3) The questionnaire started with general questions about ownership structure, size of the building, type of roof and number of rooms, floors and apartments. Then questions were raised about water facilities including numbers of sanitary units, water taps, and any possibly existing swimming pools. These were followed by questions about the type of water supply. In this part, a special focus was on the use of cisterns. The respondents were asked to answer questions about cistern capacity, about the designated use of the harvested water, and if their demands for harvested water were satisfied. Water quality from the cistern had to be rated from "excellent", over "good", "fair" to "not good". Questions about the sanitation system and about garden irrigation completed the survey.

For a subset of 79 households, cistern capacities $\left[\mathrm{m}^{3}\right]$ were reported and could be compared to connected rooftop catchment areas $\left[\mathrm{m}^{2}\right]$. To simulate continuous cistern use, a constant value of daily water consumption was subtracted from the accumulated rooftop runoff obtained by the model. For this purpose, literature values of average per capita water consumption (Magiera et al., 2006) were multiplied by the number of persons living in the individual households. The rainfall station with the largest rainfall volume $(554 \mathrm{~mm})$ was used as model input since it represented long term average rainfall. This model exercise also considered overflow when the simulated roof runoff exceeded cistern capacity. At the 


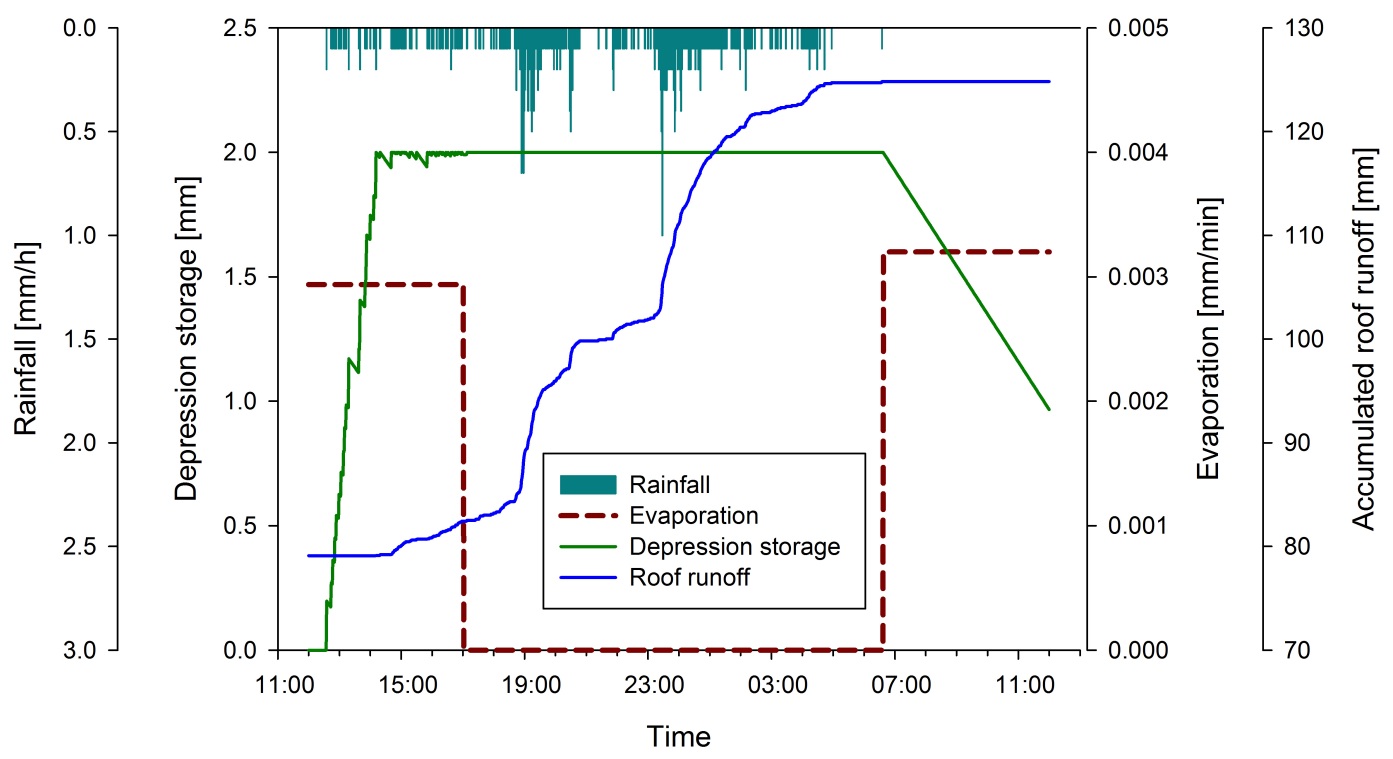

Fig. 4. Example of continuous one-minute modelling of rooftop harvesting; largest event on record, station Library, 20-21 January 2000.

end of the season, the total volume of consumed roof runoff $\left[\mathrm{m}^{3}\right]$ was divided by cistern capacity $\left[\mathrm{m}^{3}\right]$ to yield cistern efficiency [-].

\subsection{Regional RWH potentials}

For the entire LJRB, we created a contiguous GIS data layer of urban areas combining different data sources. For the Israeli part, a vector data set of 2002 delineated buildings as a distinct class. Urban areas of the PA were digitized from aerial photos with a spatial resolution of $1 \times 1 \mathrm{~m}^{2}$. In Jordan, urban areas were extracted as a distinct pixel value class $\left(78 \times 78 \mathrm{~m}^{2}\right)$ from a 2002 land use map and converted to vector data.

A C-Band volume scanning rainfall radar system located at Ben-Gurion international airport, close to Tel Aviv, provided regional data sets of $1.4 \times 1 \mathrm{~km}$ (polar coordinates) rainfall during an average season (2002/2003) and during a drought (1998/1999). Five-minute radar data was obtained from E. Morin (Hebrew University of Jerusalem, Israel), after pre-correction by a multiple regression approach (Morin and Gabella, 2007). This data was converted to a $1 \times 1 \mathrm{~km}^{2}$ grid, regionalized to the LJRB and calibrated by station data (Gunkel and Lange, 2011). The Jordanian parts of the LJRB outside a $150 \mathrm{~km}$ range around the location of the rainfall radar had to be excluded due to uncertainties in rainfall estimates.

For both rainfall seasons, a GIS overlay of $1 \times 1 \mathrm{~km}^{2}$ annual rainfall volumes and the urban vector data set yielded the annual rainfall that fell on urban areas. This data set was multiplied by factor 0.2 due to the fact that approximately $20 \%$ of urban areas in the Middle East are covered by roof areas (Grodek et al., 2011). To obtain volumes of urban RWH, the data was multiplied by a variable roof runoff coefficient $\mathrm{RC}$. RC was varied according to a linear regression found between annual rainfall amount and simulated $\mathrm{RC}$ of the rainfall stations in Ramallah. Thereby, we set the lower boundary for the RC values at 0.7 and the upper boundary at 0.9 .

\section{Results}

\subsection{Amount of harvested rainwater}

Considering typical roof types in Ramallah, DS was set to $2.0 \mathrm{~mm}$. Then the model was run in a one-minute step for all rainfall stations available. It included the basic dynamics of rainwater harvesting as seen during a large rainstorm (Fig. 4). The event of 20-21 January 2000 was the main storm of a two-storm high magnitude event, which was the largest on our measurement record and produced big floods in the urban drainage system (Grodek et al., 2011). According to the model, roofs were dry at the onset of rainfall. DS slowly filled by low intensity rainfall from 12:30 until 14:00 LT. The main storm occurred during night. Due to zero evaporation, DS remained full and more than $40 \mathrm{~mm}$ of water could be harvested. After sunrise, DS was emptied by evaporation.

When the seasonal RC-values of all rainfall stations were plotted against recorded rainfall, an increase of RC with annual rainfall depth was noticed (Fig. 5). For low annual rainfall values, a large scatter was observed with single RC values plotting outside the $95 \%$ confidence band of the regression. This was mainly an effect of the short recording periods. When a single high intensity rainfall event occurred during the period of record (an example is shown in Fig. 4), RC values were relatively high, even at little total rainfall. Above 


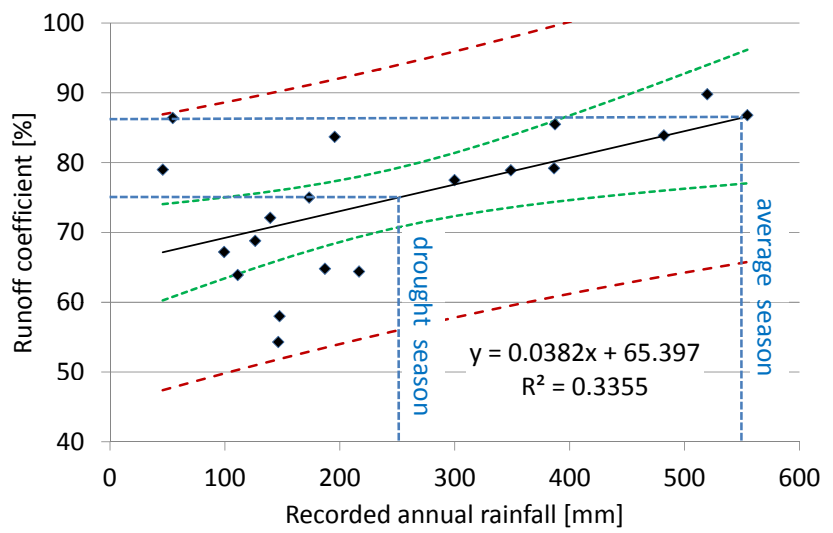

Fig. 5. Annual RC values calculated for all stations plotted against annual rainfall; DS is set to $2 \mathrm{~mm}$; dashed lines show $95 \%$ confidence band (green) and $95 \%$ prediction band (red).

$300 \mathrm{~mm}$ of annual rainfall, RC values were more alike, because they contained a relatively similar rainfall intensity spectrum. The $95 \%$ prediction band was used to estimate RC uncertainty.

For Ramallah this data suggested a RC of $75 \%$ (56$94 \%)$ for a drought season $(250 \mathrm{~mm}$ rainfall) resulting in $190 \mathrm{~mm}(140-240 \mathrm{~mm})$ of rooftop runoff. For an average season $(550 \mathrm{~mm})$ a reasonable RC estimate was about $87 \%$ (66-100\%) which resulted in approximately $480 \mathrm{~mm}$ (370$550 \mathrm{~mm}$ ) of rooftop water. The season 1999/2000 at four stations was selected to study the effect of a changing limit in DS on roof runoff coefficients (RCs) (Fig. 6). DS was changed according to literature values. It can be noticed that in the range of reported values for DS, annual RCs for single stations vary by about $5-10 \%$.

\subsection{Survey of local residents and cistern efficiency}

At the time of the survey, 577 separate buildings existed in the selected $1.3 \mathrm{~km}^{2}$ district of Ramallah with a total roof area of about $154000 \mathrm{~m}^{2}$ (Fig. 3). 36 were uninhabited (under construction, functional buildings, etc.) and excluded from the questionnaire survey. From 541 distributed copies of the questionnaire, 513 were re-collected yielding a response rate of $95 \% .78 \%$ of the buildings had flat concrete roofs, $97 \%$ had access to the public water supply, but only $2 \%$ had private swimming pools. $83 \%$ were connected to the public sanitation network, the remaining buildings used cesspits for waste water disposal. Households were inhabited by 5.1 persons on average, which used 1.8 showers and 3.8 water taps.

Two-thirds of the buildings had surrounding private land. According to their owners, this land had an average size of about $700 \mathrm{~m}^{2}$. From the collected questionnaires, a total area of $242000 \mathrm{~m}^{2}$ private land was calculated for the investigated city district. About $67 \%$ of this land was used as a cultivated

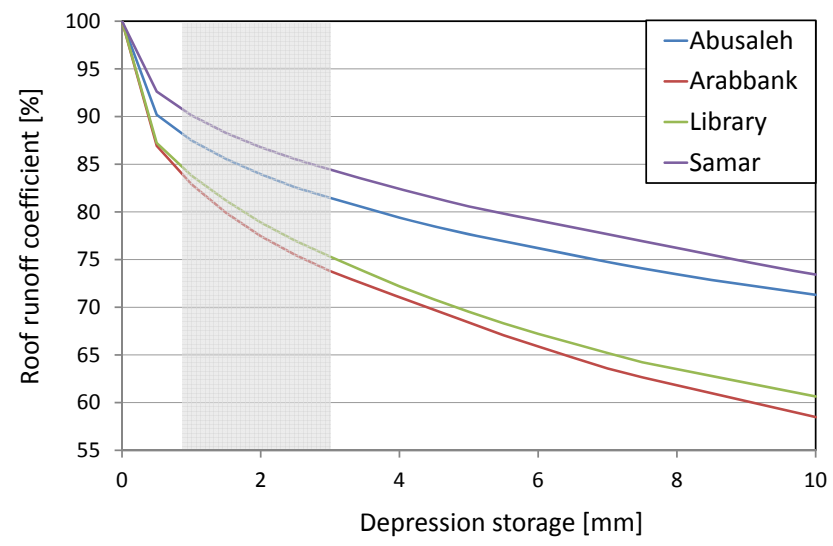

Fig. 6. Calculated RCs for different values of maximum roof depression storage DS; the shaded area (1-3 $\mathrm{mm}$ ) represents the anticipated uncertainty range accounting for different roof types; rainfall of season 1999/2000 is used as input.

garden and $60 \%$ was irrigated, which added up to an irrigated area of approximately $144000 \mathrm{~m}^{2}, 11 \%$ of the investigated area. Asked about the source for irrigation water, $56 \%$ of garden owners reported to use water from the public water supply, whereas $44 \%$ relied on cisterns. In total, $40 \%$ of the households had cisterns installed that were filled by roof runoff. $94 \%$ of these active cisterns supplied enough water according to their owners. Rooftop runoff was used for different purposes and had good overall quality according to its users (Fig. 7).

Information about storage capacity was available for only 79 active cisterns (Fig. 8). Six cisterns plotted far above the rest and had small efficiency. Assuming a per capita water consumption of $851 \mathrm{day}^{-1}$ (Magiera et al., 2006), overflow occurred in 39 cisterns. Twelve of them had efficiencies larger than 2 indicating that they are filled more than two times during an average rainfall year. Finally, the expectancies of urban RWH during droughts and during average seasons (Fig. 5) were combined with questionnaire data and connected roof areas. The resulting volumes of rooftop water to be expected for Ramallah are summarized in Table 1.

\subsection{Regional RWH potentials}

Regional RWH potentials are summarized in Table 2. Results indicate considerable differences between the drought and the average season, especially for Jordan. Here, the drought season 1998/1999 was characterized by low precipitation especially in the eastern parts.

\section{Discussion}

For a similar climate in Spain, Farreny et al. (2011b) measured a global $62 \% \mathrm{RC}$ value for a flat gravel roof. They explained this low value by the fact that in the gravel much 
Table 1. Potentials for rooftop water harvesting in Ramallah; calculations are based on an orthophoto of 1997 and a questionnaire survey of 2000; uncertainty intervals are estimated by the $95 \%$ prediction interval of the RC-rainfall regression (Fig. 5).

\begin{tabular}{lrrll}
\hline & Number & $\begin{array}{l}\text { Total rooftop } \\
\text { area }\end{array}$ & $\begin{array}{l}\text { Rooftop runoff } \\
\text { expected for a } \\
\text { drought season }\end{array}$ & $\begin{array}{l}\text { Rooftop runoff } \\
\text { collected during an } \\
\text { average season }\end{array}$ \\
\hline Rooftop runoff [mm] & - & - & $190(140-240)$ & $480(370-550)$ \\
\hline $\begin{array}{l}\text { Houses with active cisterns in } \\
\text { the investigated city district }\end{array}$ & 149 & $33 \times 10^{3} \mathrm{~m}^{2}$ & $6(4-8) \times 10^{3} \mathrm{~m}^{3}$ & $16(12-18) \times 10^{3} \mathrm{~m}^{3}$ \\
\hline $\begin{array}{l}\text { Houses with installed cisterns } \\
\text { in the investigated city district }\end{array}$ & 223 & $53 \times 10^{3} \mathrm{~m}^{2}$ & $10(7-13) \times 10^{3} \mathrm{~m}^{3}$ & $26(19-30) \times 10^{3} \mathrm{~m}^{3}$ \\
\hline $\begin{array}{l}\text { All houses in the investigated } \\
\text { city district }\end{array}$ & 558 & $154 \times 10^{3} \mathrm{~m}^{2}$ & $29(21-37) \times 10^{3} \mathrm{~m}^{3}$ & $74(56-85) \times 10^{3} \mathrm{~m}^{3}$ \\
\hline Houses in entire Ramallah* & 2777 & $621 \times 10^{3} \mathrm{~m}^{2}$ & $118(86-147) \times 10^{3} \mathrm{~m}^{3}$ & $298(226-342) \times 10^{3} \mathrm{~m}^{3}$ \\
\hline
\end{tabular}

* Only those that were included in the available orthophoto.

Table 2. Potentials of urban RWH in different parts of the Lower Jordan River Basin for the average season 2002/2003 and the drought season 1998/1999; uncertainty intervals are estimated by the $95 \%$ prediction interval of the RC-rainfall regression (Fig. 5).

\begin{tabular}{lrrll}
\hline $\begin{array}{l}\text { Part of the } \\
\text { LJRB }\end{array}$ & $\begin{array}{c}\text { Total area } \\
{\left[\mathrm{km}^{2}\right]}\end{array}$ & $\begin{array}{c}\text { Urban area } \\
{\left[\mathrm{km}^{2}\right]}\end{array}$ & $\begin{array}{c}\text { RWH potential } \\
{\left[10^{6} \mathrm{~m}^{3}\right]}\end{array}$ & $\begin{array}{c}\text { RWH potential } \\
{\left[10^{6} \mathrm{~m}^{3}\right]}\end{array}$ \\
\hline & & & $\begin{array}{l}\text { Drought } \\
(1998 / 1999)\end{array}$ & $\begin{array}{l}\text { Average Season } \\
(2002 / 2003)\end{array}$ \\
\hline PA & 1523 & 39 & $1.34(1.01-1.66)$ & $4.29(3.78-4.90)$ \\
Israel & 979 & 22 & $0.83(0.62-1.03)$ & $2.27(1.82-2.59)$ \\
Jordan* & 6877 & 233 & $0.87(0.61-1.08)$ & $13.21(10.36-15.69)$ \\
\hline Total* & 9379 & 294 & $3.04(2.24-3.77)$ & $19.77(15.96-23.18)$ \\
\hline
\end{tabular}

* Only parts inside the $150 \mathrm{~km}$ range from the rainfall radar.
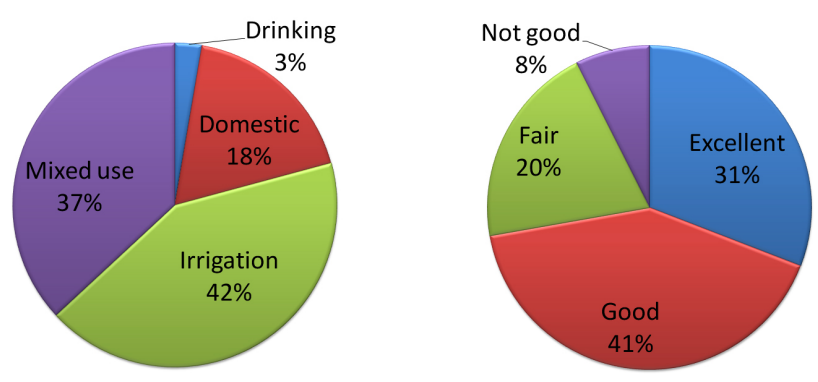

Fig. 7. Reported use and water quality of 149 active cisterns in Ramallah.

water is initially abstracted due to a great interstitial pore space. Sloping roofs had much higher RC values reaching $84 \%$ for clay tiles, $91 \%$ for plastic and $92 \%$ for metal roofs. When they plotted the amount of collected rooftop runoff per storm against rainfall, DS values could be quantified from the $x$-intercept of a linear regression model. This was successful for the clay tile $(0.8 \mathrm{~mm})$ and for the gravel roof $(3.8 \mathrm{~mm})$. In principle, our methodology was opposite. Assuming a representative value for DS, our one-parameter model calculated seasonal RC values from local measured rainfall and evaporation data. Using a 1-3 mm uncertainty range for DS, our seasonal RC values varied between 72 and $92 \%$ (Fig. 6), which compared nicely to the Spanish study. However, most of this variation was caused by different rainfall magnitudes recorded by the four different rainfall stations, rather than by different values of DS. As reported by the questionnaire survey, almost $80 \%$ of the buildings in Ramallah are covered by flat concrete roofs. Gravel roofs are totally absent. In an aerial picture, flat concrete roofs appear white to grey, while sloping clay tile roofs are characterized by a reddish colour (Fig. 9). Hence, a value of $2 \mathrm{~mm}, 0.5 \mathrm{~mm}$ below the textbook value for flat roofs, seems to be a reasonable estimate for a representative DS in Ramallah. Due to the dominance of two well defined roof types, the real uncertainty of this value seems well below our anticipated uncertainty range 


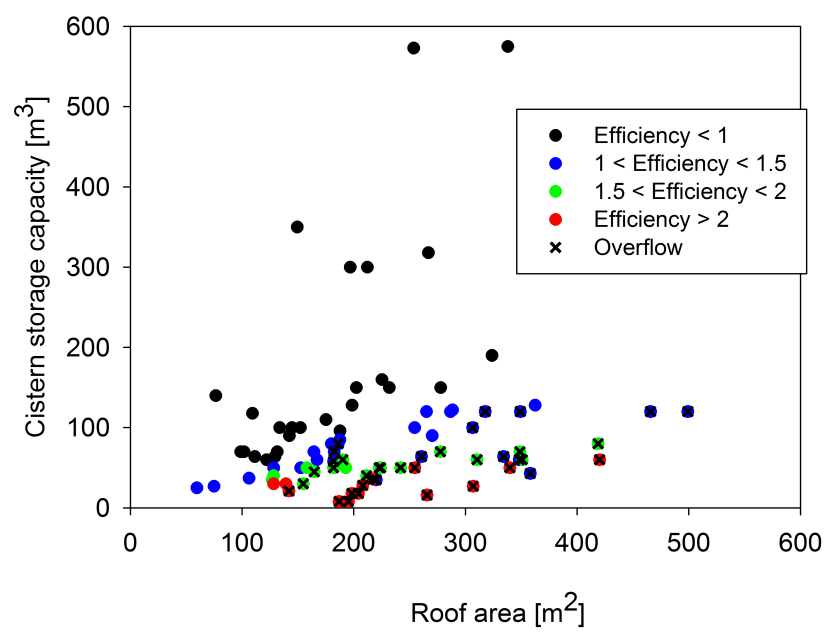

Fig. 8. Storage capacity and connected rooftop area of 79 active cisterns in Ramallah.

(1-3 mm). For entire Ramallah, the effect of roof adaptation also falls into this uncertainty range.

Inside Ramallah, Grodek et al. (2011) classified the rainfall stations into two types (valley and ridge stations), averaged operating stations of each type on an event base, and used a mean of the two types to calculate catchment rainfall. In this study we decided not to fill gaps in the rainfall records but rather use the original recordings of each station as individual inputs for our analysis. Thus, the 19 points of Fig. 5 only represent measured rainfall data of three different seasons that were collected at more or less the same location but with different recording lengths. They are not equal to a 19-yr time series of independent seasons. Since operating periods of the individual stations were determined by coincidences - this is indicated by the large scatter obtained for low rainfall in Fig. 5 - we are confident, that incomplete data records may be used to represent low rainfall conditions. Although the obtained correlation was rather weak (mainly caused by the scatter described above), our data suggests that runoff coefficients for urban RWH generally decrease during drought periods. Hence, we used this correlation and the inherent uncertainty to account for variable rainfall in our regional estimates of RWH volumes in the LJRB.

In agreement to the world-wide consensus about the good chemical water quality of rooftop runoff (e.g. Lye, 2009), our data suggests that also in Ramallah there is no basic impediment to use harvested rooftop water. Almost three quarters of the cistern users reported "good" or "excellent" water quality (Fig. 7), which is in line with the local investigation of Hassan et al. (2010), who did not find problems in the chemical quality of water collected from an urban rooftop. However, perceived water quality depends on the intended use and water can be "excellent" for irrigation but not for drinking. Moreover, these results should not be transferred to the general quality of urban storm runoff which might be poor

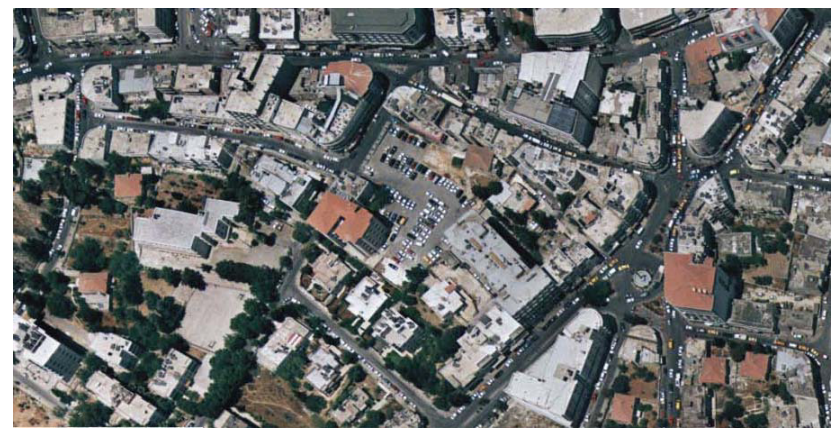

Fig. 9. Detail of the orthophoto used for GIS-analysis: the two dominant roof types in Ramallah can be identified: flat concrete roofs (grey) and sloping clay tile roofs (red).

due to urban pollution of roads or urban storm water sewers (Grodek et al., 2011). Hygienic problems were found to be the main obstacle for a widespread use of RWH in the region (Al-Saleymeh et al., 2011). Nevertheless it seems surprising that in the year 2000 only $3 \%$ of the active cisterns in Ramallah were actually used for drinking and that one-third of the installed systems were out of operation. Here, financial incentives could intensify the use of rooftop water. Relatively small investments are needed, because many systems exist and only have to be rehabilitated. During an average year, our data showed overflow in approximately $50 \%$ of the existing systems, while $8 \%$ of the cisterns were oversized (Fig. 8). We are aware that our analysis is based on 10-yr old data. Today the exact numbers of urban water use in Ramallah might have changed in the light of the ongoing water scarcity. Nevertheless, one may expect large unutilized potentials for urban RWH still today.

Despite hygienic constraints, urban RWH may be seen as a valuable contribution to emergency water supply, since stored cistern water may individually bridge breakdowns of water distribution networks. During an average year, installed RWH systems provided backup water for a time period of one month up to an entire year depending on storage capacity, connected roof area and number of persons living in the households (Fig. 10). They provided up to $162 \mathrm{~m}^{3}$ of water and hence may have saved up to $100 €$ considering a local water price of $0.62 € \mathrm{~m}^{-3}$ (Magiera et al., 2006).

The reliability of our regional estimates for the LJRB mainly depends on the used input data. First, our data represents single seasons and should not be taken for long term averages. Second, the accuracy of the rainfall radar decreases with distance to the radar antenna which makes annual rainfall volumes more uncertain in Jordan. Third, a $20 \%$ coverage of roof areas for all cities and a uniform DS value $(2 \mathrm{~mm})$ should only be seen as a rough estimate. And fourth, the spatial resolution of the GIS input data for urban areas in Jordan is not as detailed as those for the PA or for Israel. Still, our results in Jordan $\left(13.2 \times 10^{6} \mathrm{~m}^{3}\right.$ for our individual rainfall season 2002/2003, Table 2) compared nicely to the 


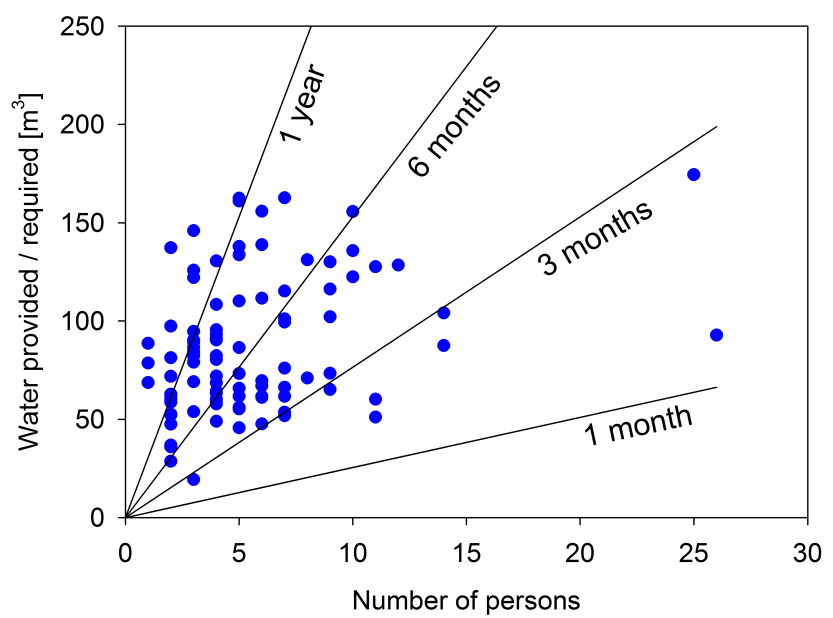

Fig. 10. Number of persons and amount of RWH supplied for 79 households with active cisterns in Ramallah; lines illustrate required drinking water assuming a per capita water consumption of 851 day $^{-1}$ (Magiera et al., 2006).

regional estimates of Abdulla and Al-Shareef (2009), who arrived at $15.5 \times 10^{6} \mathrm{~m}^{3}$ for entire Jordan. Population growth rates in the PA is among the world's highest (Tabutin and Schoumaker, 2005). Therefore, urban areas in the PA and in the neighbouring countries will constantly grow in the near future. Consequently, the importance of urban rainwater harvesting as a renewable alternative to conventional supply by water networks will increase as well.

\section{Conclusions}

Our analysis combined quantitative simulations of generated rooftop runoff with an extensive questionnaire survey of urban water use in the Mediterranean Arab town of Ramallah. Driven by one-minute rainfall data and measured potential evaporation, our one-parameter model facilitated realistic estimates of urban rainwater harvesting potentials for Eastern Mediterranean climate. Model simulations suggested that rooftop runoff coefficients strongly depend on seasonal rainfall amount. While during an average season a $87 \%$ runoff harvest (490 from $550 \mathrm{~mm}$ of rainfall) can be expected, this value decreases to about $75 \%$ (190 from $250 \mathrm{~mm}$ of rainfall) during drought seasons.

A questionnaire survey in the year 2000 suggested that inside a $1.3 \mathrm{~km}^{2}$ urban district about $40 \%$ of the urban houses were equipped with a RWH system from which one third was out of use. Although the water quality was perceived to be favourable, only $3 \%$ of the active RWH systems were actually used for drinking and only $18 \%$ for domestic purposes. Most RWH systems served for irrigation of private gardens covering about $11 \%$ of the investigated urban area. A relation with connected rooftop areas indicated overflow in approximately $50 \%$ of the installed cisterns during an average season. All active RWH systems may harvest approximately $16 \times 10^{3} \mathrm{~m}^{3}$ of rooftop runoff during an average season and $6 \times 10^{3} \mathrm{~m}^{3}$ during droughts. When these numbers are extrapolated to all houses in Ramallah, theoretical maximum potentials increase to approximately $298 \times 10^{3} \mathrm{~m}^{3}$ during average seasons and $118 \times 10^{3} \mathrm{~m}^{3}$ during droughts. Our data shows that a part of this potential can easily be exhausted by rehabilitation of installed RWH systems. To fully utilize RWH benefits the use of collected water for emergency water supply should be advocated, although care is needed because of hygienic problems. In our regional estimates for the entire LJRB the drought impact was even more significant. While during the average season 2002/2003 almost $20 \times 10^{6} \mathrm{~m}^{3}$ could be harvested from all urban roofs inside the basin, this value decreased dramatically to approximately $3 \times 10^{6} \mathrm{~m}^{3}$ during the drought season 1998/1999. As already shown by Abdulla and Al-Shareef (2009), urban RWH is a relatively small contribution to overcome water scarcity in the region. Especially during droughts only small water volumes should be expected. However, urban RWH is a sustainable water resource, which is available on spot for everybody and will increase in importance in the future because of population growth and ongoing urbanization.

Acknowledgements. This study has been funded by the German Ministry for Education and Research (BMBF) in the framework of the GLOWA Jordan River Project. J. Strub helped in drawing the figures and M. Stölzle in the uncertainty analysis. The ideas of the two anonymous reviewers significantly improved the manuscript.

Edited by: S. Uhlenbrook

\section{References}

Abdulla, F. A. and Al-Shareef, A. W.: Roof rainwater harvesting systems for household water supply in Jordan, Desalination, 243, 195-207, 2009.

Akan, O. A. and Houghtalen, R. J. : Urban hydrology, hydraulics, and stormwater quality-Engineering applications and computer modeling, John Wiley and Sons, Inc., Hoboken, New Jersey, 2003.

Al-Salaymeh, A., Al-Khatib, I., and Arafat, H.: Towards Sustainable Water Quality: Management of Rainwater Harvesting Cisterns in Southern Palestine, Water Resour. Manag., 25, 17211736, 2011.

Amin, M. T. and Han, M. Y.: Roof-harvested rainwater for potable purposes: Application of solar collector disinfection (SOCODIS), Water Res., 43, 5225-5235, 2009.

Basinger, M., Montalto, F., and Lall, U.: A rainwater harvesting system reliability model based on nonparametric stochastic rainfall generator, J. Hydrol., 392, 105-118, 2010.

Brooks, D. and Trottier, J.: Confronting water in an IsraeliPalestinian peace agreement, J. Hydrol., 382, 103-114, 2010.

Evans, C. A., Coombes, P. J., and Dunstan, R. H.: Wind, rain and bacteria: The effect of weather on the microbial composition of roof-harvested rainwater, Water Res., 40, 37-44, 2006. 
Evenari, M., Shanan, L., and Tadmor, N.: The Negev, the challenge of a desert, Harvard University Press, Cambridge, England, 1982.

Farreny, R., Gabarrell, X., and Rieradevall, J.: Cost-efficiency of rainwater harvesting strategies in dense Mediterranean neighbourhoods, Resour. Conserv. Recy., 55, 686-694, 2011a.

Farreny, R., Morales-Pinzón, T., Guisasola, A., Tayà, C., Rieradevall, J., and Gabarrell, X.: Roof selection for rainwater harvesting: Quantity and quality assessments in Spain, Water Res., 45, 3245-3254, 2011b.

FOME: Towards a living Jordan River: An environmental flows report on the rehabilitation of the lower Jordan River. EcoPeace/Friends of the Earth Middle East (FOME), Amman, Bethlehem, Tel Aviv, 2010.

Grodek, T., Lange, J., Lekach, J., and Husary, S.: Urban hydrology in mountainous middle eastern cities, Hydrol. Earth Syst. Sci., 15, 953-966, doi:10.5194/hess-15-953-2011, 2011.

Gunkel, A. and Lange, J.: New insights into the natural variability of water resources in the Lower Jordan River Basin, Water Resour. Manag., online first: doi:10.1007/s11269-011-9903-1, 2011.

Hassan, M. A., Shahin, K., Klinkenberg, B., McIntyre, G., Diabat, M., Tamimi, A., and Nativ, R.: Palestinian Water II: Climate change and landuse, Geography Compass, 4, 139-159, 2010.

Helmreich, B. and Horn, H.: Opportunities in rainwater harvesting, Desalination, 248, 118-124, 2009.

Hollis, G. E. and Ovenden, J. C.: The quantity of stormwater runoff from ten stretches of road, a car park and eight roofs in Hertdordshire, England during 1983, Hydrol. Process., 2, 227-243, 1988.

Jones, M. P. and Hunt, W. F.: Performance of rainwater harvesting systems in the southeastern United States, Resour. Conserv. Recy., 54, 623-629, 2010.

Kittani, H.: Water Harvesting in Palestine, the 2nd International Conf. on Water Resources and Arid Environment, King Saud University, Riyadh, Saudi Arabia, 2006.

Klein, M.: Water Balance of the Upper Jordan River Basin, Water Int., 23, 244-248, 1998.

Lye, D. J.: Rooftop runoff as a source of contamination: a review, Sci. Total Environ., 407, 5429-5434, 2009.
Magiera, P., Taha, S., and Nolte, L.: Water demand management in the Middle East and North Africa, Management of Environmental Quality, 17, 289-298, 2006.

Mendez, C. B., Klenzendorf, B., Afshar, B. R., Simmons, M. T., Barrett, M. E., Kinney, K. A., and Kirisits, M. J.: The effect of roofing material on the quality of harvested rainwater, Water Res., 45, 2049-2059, 2011.

Morin, E. and Gabella, M.: Radar-based quantitative precipitation estimation over mediterranean and dry climate regimes, J. Geophys. Res.-Atmos., 112, D20108, doi:10.1029/2006JD008206, 2007.

Morin, J., Sharon, D., and Rubin, S.: Rainfall intensities in Israel, Research Report, Hebrew University of Jerusalem, 46-53, 1994.

Palla, A., Gnecco, I., and Lanza, L. G.: Non-dimensional design parameters and performance assessment of rainwater harvesting systems, J. Hydrol., 401, 65-76, 2011.

Rygaard, M., Binning, P. J., and Albrechtsen, H.-J.: Increasing urban water self-sufficiency: New era, new challenges, J. Environ. Manage., 92, 185-194, 2011.

Sazakli, E., Alexopoulos, A., and Leotsinidis, M.: Rainwater harvesting, quality assessment and utilization in Kefalonia Island, Greece, Water Res., 41, 2039-2047, 2007.

Sharon, D. and Kutiel, H.: The distribution of rainfall intensity in Israel, its regional and seasonal variations and its climatological evaluation, J. Climatol, 6, 277-291, 1986.

Srinivasan, V., Gorelick, S. M., and Goulder, L.: Sustainable urban water supply in south India: Desalination, efficiency improvement, or rainwater harvesting?, Water Resour. Res., 46, W10504, doi:10.1029/2009WR008698, 2010.

Tabutin, D. and Schoumaker, B.: The Demography of the Arab World and the Middle East from the 1950s to the 2000s - a Survey of Changes and a Statistical Assessment, Population (english edition), 2005/5, 60, 505-615, 2005.

Thomas, P. R. and Greene, G. R.: Rainwater Quality from Different Roof Catchments, Water Sci. Technol., 28, 291-299, 1993.

Zhu, K., Zhang, L., Hart, W., Liu, M., and Chen, H.: Quality issues in harvested rainwater in arid and semi-arid Loess Plateau of northern China, J. Arid Environ., 57, 487-505, 2004. 